\title{
Political Activism and Workplace Industrial Relations in a UK 'Failing' School
}

\section{Moira Calveley and Geraldine Healy}

\begin{abstract}
The paper draws on a qualitative case study of workplace industrial relations in an innercity secondary school identified as 'failing' and subsequently closed. It considers the way unionized teachers and their representatives interpret, influence and resist the impact of centralized managerial and educational change. The local implementation of such change leads to an engagement with the debates on union renewal. In particular, the paper explores the dynamic interrelationship between political and trade union activism and the tension between workplace relations and formal union organization.
\end{abstract}

\section{Introduction}

The paper explores the relationship between trade union activists, their members and their union in 'Parkville', a UK inner-city secondary school, identified as 'failing' and subsequently closed. The impact of new managerialism on workplace activism is considered showing how decentralized management initiatives inflamed industrial relations tensions at school level, how teachers collectively resisted new managerialism, and, importantly, how this resistance was fuelled by a local union activist, also a political activist. By engaging with the union renewal debate, the paper draws attention to the neglected link between trade union activism and political activism, and in this context revisits the uneasy relationship between unions as representative organizations and as 
oligarchies. Finally, the extent to which conditions in the school promote or hinder union renewal, resilience and, as it emerges, degrees of retreat is explored.

The paper is set against the backdrop of radical educational reform in England and Wales. The 1988 Education Reform Act (ERA) introduced 'centralized decentralization' (Hoggett 1996: 18) into education through centralized curriculum control and a devolved system of management through the local management of schools (LMS). LMS has created a managerial role for headteachers, with responsibility for financial and human resources devolved to local school managers from the local education authority (LEA). This shift to what has become known as 'new managerialism' is well documented, but its interrelationship with industrial relations in teaching at the workplace level is less so (exceptions include Healy 1997; Ironside and Seifert 1995; Sinclair et al. 1996). However, other studies in the public sector have suggested that decentralization to local management may be an important catalyst for union renewal (Fairbrother 2000a; Thornley 1998).

New managerialism has changed the nature and balance of teachers' work and, unsurprisingly, has been met with criticism as 'professionality is replaced by accountability, collegiality by costing and surveillance' (Ball 1994). Public accountability has also been introduced through school league tables ${ }^{2}$, the rhetoric of which is to identify 'good' and 'bad' schools. Schools at the top of the 'league' have both pupils and staff competing to enter them, while those at the bottom face under-subscription and 
possible closure, thus subjecting schools to 'market mechanisms' (Sinclair et al. 1996: 641). This division between schools was reinforced by New Labour's publicly targeting under-performing schools to raise standards; the practice, since rescinded, was known as 'Naming and Shaming'.

These changes took place in the context of a profession which is characterized by high union density. Competitive multi-unionism is entrenched with teachers organized in six unions ranging from the more militant National Union of Teachers (NUT), National Association of Schoolmasters and Union of Women Teachers (NASUWT), to the antistrike Professional Association of Teachers (PAT). As John Kelly asserts, teachers display a wide range of political orientations (Kelly 1998: 138). This is evident in the choice of union and the contestations between factions within unions, manifesting itself at the national and, of relevance to this paper, local level through the influence of activists.

\section{Activism, political factions and trade unions}

The importance of local union leadership to workplace union activity is well documented (Darlington 1994, 1998, 2001; Fosh 1993; Greene et al. 2000) and is a recurrent theme in the debates on union renewal. Indeed, according to Fosh, 'the possibility for union renewal comes through building up the base level of participation by careful local leadership so that members can more easily be encouraged to take part in collective activities in times of necessity' (Fosh 1993: 577). Similarly, Fairbrother (1994, 1996) suggests that, despite the recent trend of decline in union membership, as management 
initiatives have been devolved to the local level and 'more participative forms of unionism' (1996: 141) have emerged there is a possibility for union 'renewal' (1990). The broad essence of Fairbrother's argument is that in the public sector a more decentralized and devolved form of management has developed, albeit within the confines of centralized government controls, with a corresponding devolvement of industrial relations issues. Consequently, workers have turned to their immediate trade union representatives for assistance, thereby increasing local union activity, which in turn encourages union renewal in the workplace (Fairbrother 1990, 1994, 1996). Renewal is seen as comprising a set of processes concerned with union survival and development within the workplace - the recruitment and replenishment of new generations of activists, the building of workplace activity in the context of restructuring, the development and promotion of mutual support between levels of union members and leaders, and (outside the remit of this paper) the conditions for international unionism (Fairbrother 2000a: 4778).

The renewal thesis is not without its critics. Fitzgerald and Stirling, in their study of the Fire Brigades Union, suggest that it is more appropriate to characterize union activity in terms of resilience than renewal (1999: 47). Carter and Poynter similarly have reservations and suggest that 'to see the possibility [of renewal] is not necessarily to see its fulfilment' (1999: 510). McIlroy dismisses the renewal thesis as being 'slender and drawn from a small number of case studies' (1995: 138). He claims that 'decentralization diminishes the utility of national co-ordination and the deployment of external power unavailable in the enterprise. It is a sign of weakness, not strength' (1995: 138). Further 
cautionary observations emerge from Colling's (1995) study of contracting in local government, which indicates that local union structures may be too fragile to withstand managerial and competitive pressures. The particular conditions emerging from managerial change may have common broad objectives, but the different processes and specific aims involved suggest that some care must be taken in treating the public sector as an homogeneous entity. Notwithstanding these critiques, Gall argued that 'even if all the studies did show little evidence of renewal this would not necessarily invalidate Fairbrother's thesis in that he was attempting to identify the conditions or basis for renewal' (Gall 1998: 156). For Gall, the prospects for renewal need to be judged at different points in time when the potential will be greater or lesser (1998: 152). Nevertheless, he questioned Fairbrother's lack of acknowledgement of political agency, which he suggests should be added in 'recognition of the important part played by the politics of the workplace union leadership and activists' (1998: 154). Indeed, Darlington (1994, 1998, 2001), Gall (1998) and McIlroy (2000) all suggest that the political orientations, particularly of left-wing activists, play a significant role in workplace union activity. While Fairbrother (2000b) acknowledges Gall's critique, he argues that, 'unless such groups are both in and of the union form, their contribution is necessarily limited to that of the outsider' (p. 330). Notwithstanding the previous discussion, Kelly's observation that there is very little literature on political factionalism in unions, despite 'fierce debates' between different parties (1998: 54), indicates that this topic deserves deeper attention. 
Factions at different levels within unions may cause consternation among the union bureaucracy, which has the legitimacy of its practices and policies challenged by the members. However, it has long been acknowledged that challenges and opposition are important to trade union democracy (Darlington 1994; Lipsett et al. 1956; Shepherd 1949). Factions are important in the challenges to Michels's (1915) 'iron law'; for example, for Martin (1968) union democracy is about the survival of faction. More recently, Cornfield's (1993) work on insurgency explores the diverse forces that erode oligarchy, and Healy and Kirton (2000) show how women's factions challenge union oligarchy. However, the relationship between faction and union democracy is not unproblematic. For example, Seifert proposes that in the case of the NUT the 'exaggerated warring between the left groups ... enabled the Union to fall under the control of an increasingly pro-Labour Party set of officials and national local leaders' (1987: 125). Under certain conditions, therefore, competitive factions may reinforce the dominant groups.

Gall (1998) distinguishes between two political factions that are active in the workplace, the Broad Left/Militant and the Socialist Workers' Party (SWP); the former looks to influence unions through becoming part of the union bureaucracy, while the latter 'seeks to build a network of socialists and militants, based in the workplaces, whose task is to lead fights based in and around the workplace' (Gall 1998: 154-5). Darlington argues that left-wing leaders or shop-stewards "with an overtly ideological and solidaristic . . . commitment to trade unionism' have a crucial role in mobilizing workers 'for collective action against management' (2001: 3). An important strength of political factions is that 
their members support one another across sectoral boundaries and 'act as a link between different workplaces both through their own organizations and through the shop stewards networks' (Gall 1998: 155).

Political activism is further linked to the sectional nature of some trade unions on which it may feed and develop. The NUT, the union central to this study, is one such case. The largest and oldest of the teacher unions, it is characterized by factionalism and viewed as the more politically 'left' of the trade unions, probably because of the visibility of an ‘organized left wing presence' (Ironside and Seifert 1995: 103).

Contrary to Seifert's (1987) view regarding the 'warring between the left groups' in the NUT (above), McIlroy (2000) suggests that, compared with other unions, there is a high degree of informal collaboration between these factions. The open factionalism, reflecting strong 'socialist and feminist traditions of activity' within the NUT (unlike other teacher unions), is acknowledged as having an important part to play in the operation of the union (Ironside and Seifert 1995) ${ }^{3}$. Indeed, despite his critique of factions, Seifert himself identified their recruiting benefit in his study of the now obsolete Rank and File, a SWP faction of the NUT, whose strength was in 'its ability to attract active union members' (1984: 375).

However, regardless of political affiliation, workplace union activity varies over time, with members becoming more active if there are issues with which they are concerned 
(Fosh 1993: 581). To understand such activism, this paper draws on the interrelated concepts of renewal and retreat.

The concept of retreat helps to characterize the interrelationship between periods of high and low activism. Retreat operates in a conflict-oriented situation, where an appraisal of the conditions by workplace activists or the union leads to a pragmatic or forced decision to restrain workplace activism. This does not suggest a reduction of union orientation, nor the impossibility of regrouping under different circumstances. Thus, the union orientation will assume a degree of constancy within the same or different employment contexts, but this is contingent on the conditions faced at a moment in time.

Before exploring the key themes of the paper, the following section provides a brief explanation of the research approach.

\section{Method}

The case study was undertaken over an 18-month period between 1998 and 2000. The

research, informed by an earlier study ${ }^{4}$, was designed to provide qualitative insights into the impact of devolved management on industrial relations in an inner-city school. The direction of the research took on its own momentum when, just before the fieldwork began, it was announced that the school was to close in 18 months' time. By drawing on a variety of methods to 'give voice' to the key actors, the research process led to the emergence of the main themes. The paper is organized around these themes: (a) 
workplace activism and new managerialism; (b) workplace leadership and politics and (c) workplace representation and union oligarchy.

Forty-eight face-to-face in-depth interviews were carried out. The issues explored were:

- position of the school,

- management initiatives,

- trade union action,

- appraisal,

- goodwill,

- redundancy,

- union membership,

- lay and official representation,

- perceptions of: activism, politics in the workplace, union bureaucracy, militancy, and reactions to the SWP.

Those interviewed were the headteacher, deputy headteachers (three), acting head, teaching staff $(24)^{5}$, support staff, governors, a LEA official, local union representative, regional lay organizer and paid union official. All but three interviews were taped and fully transcribed, and anonymity was assured. Participant observation as a teacher's assistant for two one-week periods and attendance at school meetings and social events were undertaken. During the process many informal discussions took place, often in the staff room or the school dining room. The study also drew on documentary evidence 
from the union, LEA and governors' meetings, as well as from media coverage by local and national newspapers, television and radio.

Access to the school was through agreement with the headteacher, however access to the teachers proved more difficult. At this time articles were appearing in the local press which, drawing on the views of the headteacher and the LEA, held the teachers responsible for the failure of the school. This helps explain teachers' initial reluctance to be interviewed. During the course of the case study, and in particular following the first period of participant observation, the teachers became more willing to participate. Throughout, this was a difficult and sensitive research environment.

\section{The case study: Parkville, a 'failing' school}

\section{The School}

Parkville was an inner-city secondary school, considered as 'failing' and situated at the lower end of the school league tables. Examination results at Parkville were consistently below the national average, pupil turnover was high, the majority of students came from socially and economically dis-advantaged backgrounds, and more than half were from families for which English was not the home language. The school buildings were poorly maintained, making both working and studying conditions unpleasant and in some instances a matter of health and safety concern. Against the wishes of many parents, most of the staff and some of the governors, the LEA, with the permission of the Secretary of State for Education, decided to close Parkville and reopen it under the 'Fresh Start' ${ }^{6}$ initiative. 
Following the announcement of the school's closure, the management and staff were advised that they would be offered severance terms. The NUT negotiated that staff applying for a job in the new school would be guaranteed an interview (four were appointed). The headteacher resigned six months after the closure announcement; his role was undertaken by a deputy who saw the school through its final year to closure.

The press criticism of Parkville teachers included a national Sunday paper article which suggested that 'militant left-wing teachers have been largely marginalized . . . but in schools such as Parkville, they remain a potent force ${ }^{77}$ and that the teachers practised 'old-style union confrontation'. A local paper suggested that the headteacher's attempts to improve the school had been blocked by 'the militant staff, many allied to the Socialist Workers' Party'. Yet, of the 36 teachers employed at the start of the research, only two were members of the SWP. One newspaper article went as far as to suggest that the school was being closed down in order to 'get rid of staff whose traditional politics are an embarrassment to Blairite councillors'. The majority of teachers expressed a strong union orientation, but, because of the perceived influence of the SWP in the school, political activism became an important theme in this study.

Union (mainly NUT) density in the school was virtually 100 per cent. (This declined with the increasing number of supply teachers employed during the closing period.) Union organization in the school was complex. The NUT representative kept a very low profile and tended to raise non-confrontational issues ${ }^{8}$, relying on a SWP member (also the 
teacher representative on the governing body and a former NUT representative) to voice contentious issues such as redundancy. Before the school closed, the SWP member again became the NUT representative ${ }^{9}$.

A dominant ideology in the school reflected the early aims of the NUT, where the union was to benefit not only the teacher but also the working-class child, "who was to be given as broad a literary and scientific culture as was thought necessary for the child of the middle class' (Webb 1915). The social class and disadvantage of the pupils in Parkville were, by teachers' own assertions in interviews and informally, important motivating factors for their working at Parkville.

\section{Workplace Activism and New Managerialism}

Parkville experienced the effects of new managerialism more harshly than most schools because of its precarious budget position and perceived poor performance in the national league tables. The impact of LMS undoubtedly fostered discontent and created the structural conditions for direct challenges, thus increasing local union activity as posited by Fairbrother (2000a: 47-78).

The effect of devolved management was described by a deputy head of Parkville:

'Before LMS. . . it would have been the authority that's doing the dirty work and not the head, but now the head has to do that.' (deputy head 2) 
The challenge to managerialism was entrenched prior to the closure announcement. This was particularly manifest in the refusal to co-operate with the statutorily imposed performance appraisal scheme:

'There was resistance [to appraisal], union resistance and staff resistance ... because of the resistance we couldn't take it up.' (deputy head 1)

This example provides important evidence of resistance to the introduction of appraisal in schools, despite its statutory backing. Such resistance indicates a local collectivism resulting from nationally imposed change, giving fuel to the renewal debate.

Workplace tensions were compounded when, three years prior to closure, Parkville's headteacher introduced staff cuts to reduce an inherited budget deficit. As he explained:

'We went through a programme of voluntary redundancies, not without coercion of course - people had to be persuaded to take voluntary redundancy, and we reduced the staff count by nearly four.' (headteacher)

Teachers were subsequently closely monitored (by Her Majesty's Inspectorate (HMI)), and this led to the instigation of "competency procedures ${ }^{10}$ for some teachers. Withdrawal of goodwill (i.e. the undertaking of lunchtime and after-school activities) was the form of resistance adopted to counter these management initiatives. There were ebbs 
and flows in the withdrawal of goodwill; at each new initiative the resistance was reviewed and reinforced, supporting Fosh's (1993) view that workplace activity is not a static phenomenon.

On being asked about workplace activity, a teacher explained:

'[The headteacher] decided that he was on one side ... and the staff were on the other side, and he was on the good side and the staff were on the bad side.' (teacher 7)

Illustrating the renewal thesis, another commented:

'We've all been driven together in defence. By doing what he did [the headteacher] helped to create a much stronger union!' (teacher 10)

The above comments indicate that the devolvement of management issues to the local level heightened industrial relations activity and tensions within the school. It was this preparedness to resist that led to the branding of teachers at Parkville as 'militant' by the headteacher, the LEA and the local and national press. In Parkville the concept of 'militant' and 'militancy' was socially constructed, reflecting diverse values on the school. Thus, when asked whether she thought the staff in the school were militant, one teacher had this to say: 
'If [the headteacher] means the staff are angry about the school closing and they don't want it to, then yes, we are all militants, you know. Do we want decent working conditions? Yes. Are we prepared to fight for them? Yes. Do we want - are we prepared to stand by and see our colleagues victimised and do nothing about it? No. You know, now if those things are militant then we're all militants.' (teacher 12)

This section has demonstrated how new managerialism is creating the conditions for discontent and union activism; the extent to which these conditions lead to renewal is contingent on other factors, including local leadership.

\title{
Workplace Leadership and Politics
}

In Parkville the teachers had a history of trade union action and adherence to national union policy making:

\begin{abstract}
'Whenever the national union has called on us to take industrial action we've always been willing to do it - over whatever issue . . like ambulance workers and that.' (teacher 8)
\end{abstract}

In keeping with Fosh's (1993) argument, local union leadership was an important aspect of workplace activity at Parkville, and, as the above quotation demonstrates, staff operated in a union oriented workplace. The case study allows a consideration of the neglected role of the political activist in the renewal debate (Gall 1998: 154), since the most prominent union activist was also a political activist. Throughout the fieldwork his 
presence was highly visible, and other teachers turned to him to raise issues, as was evident from observed staff meetings and a meeting with a LEA official. When questioned on his union involvement, he responded that:

'The members of the SWP have a responsibility to play an active part in their trade union',

emphasizing the relationship between his political commitment and work-place activism (see Darlington 2001). Just as political activists (such as those at Parkville) become workplace activists, so management analyses and interprets such interventions as extremist and therefore unacceptable in workplace industrial relations. Indeed, at Parkville, in the minds of the press, the LEA and some of the senior management, the term 'militant' became synonymous with the SWP. This politically motivated 'labelling' (following Ball 1987) is another very powerful mechanism for diverting opposition, casting it as outside the accepted framework of political action (1987: 142). In this case, such labelling became part of the discourse to legitimate the closure of the school.

Mindful of the SWP objectives to build a network of workplace activists (Gall 1998), it was the case in Parkville that, despite there being only two SWP members in the school, they did not work in isolation since there was a network of SWP teachers within the local education area. The area negotiating secretary estimated that there were about ten NUT SWP members within the area, and that their existence was a cause of disquiet among the educationalists in the area. 
Further support for workplace activity in Parkville came from a core group of teachers, which was also central to the deliberations on action and resistance. While other teachers were less involved in these exchanges, the interviews indicated that the majority of teachers in the school agreed with and supported the union views of the SWP activist. However, they were unhappy - indeed, in some cases extremely angry - at being publicly associated with the SWP. This reinforces the complexity of the relationship between the teachers and the activist to whom they looked to voice their workplace concerns, but whose political allegiance they did not share and from which they distanced themselves. At the same time as adopting a critical and sometimes detached stance from the SWP, the teachers in Parkville valued activists' ability to fuel and sustain action:

'I don't like the SWP per se, but you've got to appreciate some of the energy that some of the people who are active SWP members have.' (teacher 14)

At a different level, a school governor acknowledged the SWP role:

'The SWP. . tickle everybody's conscience. There's something in there that reacts to, in all of us, to what they say. They can make us all feel guilty.' (governor 1)

However, SWP members are generally not displeased at the militant association (Callinicos 1995). When asked whether he saw himself as being militant, the union representative replied: 
'I hope so yes! . . . it's a label that's stuck on you; I mean, people interpret it in a negative way when it suits them. But if it wasn't for the activists in the union, individual members, in countless cases, would have got a raw, a rawer, deal than they've had over the years when they've had to call on the union to, to represent them or fight for them.' (union representative)

This partisan evaluation recognizes that political activists make a difference but is also an acknowledgement that they are not always able to achieve all that they seek. Reflecting on the interrelationship between political and trade union activism, the union representative stated:

'I hope that we do have an influence, as a political group, among staff . . . over the years I would imagine that I have influenced people in one way or another, and I hope that it's in a positive way \pm certainly from the union point of view it has.' (union representative)

Although he indicated that this influence can be exaggerated, when asked whether he agreed with the idea promulgated by the headteacher, the press and some of the governors that the SWP was influencing the staff in the school, he had this to say:

'When people - and it's usually the authority, or certain people of a political persuasion which is different to that of the SWP - when they say that, what they mean is that 
ordinary people can't think for themselves and that they are somehow manipulated by these activists who are spinning a web of intrigue or whatever, you know.' (union representative)

An altercation between the teachers and SWP members in the school over the displaying of a SWP poster illustrated this view. Following objections to the nature and language of this overtly political poster, the SWP members were obliged to cover offending words. Those who proffer a simplistic 'agitator theory' forget that workers interpret the motivations and meanings of their representatives. In other words, the teachers demonstrated a pragmatic response to activism; they wanted the SWP there, but their support was conditional.

Nevertheless, when the SWP influence was blamed for the school's closure, the teachers' area negotiating secretary (a lay official from another school and also SWP) commented:

'You can take it as a compliment if you like as well, because the SWP make sure we have been in the forefront of all the campaigns that we have been involved in.' (area negotiating secretary)

He went on to comment on the failure of the representative to be recruited by the new school or by any other school within the LEA. The comment acknowledges the personal risk of taking an activist role: 
'He's a revolutionary socialist ... I'm absolutely certain it's political victimization. He symbolizes everything that New Labour detests and who the local Labour councillors wanted to get rid of, and it is likely that he is going to be the symbolic sacrificial lamb.' (area negotiating secretary)

The regional secretary (the full-time official) also recognized this risk:

'[He is $]$. . . active in his political party, he's very active in the union, he certainly is a militant . . . he also was one of the most successful teachers in the school.' (regional secretary)

It was on this basis that the union decided to mount a legal challenge to his dismissal because, as the regional secretary argued, he 'is being discriminated against on the grounds of union activity'.

This section has provided important insight into the motivations of left-wing political activism and its interrelationship with workplace trade unionism, as well as the potential personal costs to activists themselves. It demonstrates the complex relationship between politically active members and other unionized teachers. Parkville teachers valued indeed, expected - a critical voice in response to management actions, but they also felt that politics per se should be left outside the workplace.

Workplace Representation and Union Oligarchy 
For Fairbrother (2000a), the mutual support between levels of union members and leaders was one of the processes that make up the renewal thesis. At Parkville there appeared to be degrees of disjuncture between union members and lay officials with the paid union bureaucracy. While there was approval of lay union representation, outlined above, a feeling of frustration emerged following the regional union's reaction to the closing of the school. A not untypical comment was:

'I don't think they've really done anything to show support - we can have as many meetings as we like, but people in this school want action and the union aren't doing anything.' (teacher 11)

The NUT is bound by UK legislation to ballot members prior to taking industrial action. Just over a year before the school closed, the following comment anticipated a tardy response from the union:

'So we get the compulsory redundancy notices and it has to be instant once those are served - oh, you've got to have an indicative ballot ... They should be talking now to the LEA about how they're going to proceed with staff negotiating. Now!' (teacher 7)

The NUT members at Parkville felt somewhat neglected by the union. Two area-wide indicative ballots were finally taken. Considering that this was an area in which teachers in the past had demonstrated their support for industrial action, the turnout for the ballots was surprisingly low (both were in the region of 40 per cent), although this is clearly not 
indicative of the level of response from Parkville teachers. Nevertheless, the results gave overwhelming support to the staff of Parkville. The area negotiating secretary identified possible reasons for the low turnout: the union had acted tardily; the issue had become stale; and the school's closure had become a fait accompli. The regional secretary disagreed:

'The idea is if you'd done it six months earlier . . you'd have got a 'yes' vote, but I, I don't buy it, I think it would have been a worse vote ... that's my strong belief and that of the executive as well.' (regional secretary)

The tension between interests of members and national leadership, well documented in the literature (Michels 1915; Martin 1968; Kelly and Heery 1994; McIlroy 2000), is borne out in the case of Parkville. The synergy of support between levels of union members and leaders identified by Fairbrother (2000a) as a process in renewal is inevitably problematic and uneven. In Parkville the teachers identified a degree of compromise inherent in the NUT response to their situation. It was felt that not enough effort was put into saving the school, and then when this failed there was dis-satisfaction with action taken on redeployment. This is illustrated by the experiences of one teacher, not offered a job in the new school, who felt pressurized by the regional union into accepting a short-term job in another school:

'I felt like I was being manipulated ... we're getting feedback from the union saying that they want us to be slotted into jobs. They don't want trouble, they don't want 
strikes . . . it's [the LEA] going to be scrutinized by the Labour government.' (teacher $18)^{11}$

The area negotiating secretary confirmed that:

'There is no doubt whatsoever that he [regional secretary] wanted people to take what offers were available to them, so that there would then cease to be a problem for the union to resolve.' (area negotiating secretary)

This comment, combined with the following response from the regional secretary, further illustrates the uneasy link between lay officials and the formal union:

'I think that she was offered a post which in my view was a sufficiently reasonable alternative for her ... I wouldn't have said I pressurized her . . . I did try to explain to her why I thought this job was in her best interests to take: she wasn't going to get a very good redundancy package ... I thought, and I still believe, it would have become a permanent job . . . maybe I did pressurize her a bit.' (regional secretary)

\footnotetext{
Although the NUT is against compulsory redundancy, two teachers in Parkville were made redundant, the regional secretary did not see this as a failure from the union's point of view:
}

'I don't see it as a failure for the union ... most of (the members) were re-deployed or took voluntary packages ... So I don’t see it as a failure.' (regional secretary) 
From this perspective, the union could be perceived to have been successful in its strategy; however, and characteristic of similar situations, the inherent compromises in such agreements were at a cost to individual members.

The decision of the national union to delay balloting for strike action in an area where the teachers are known to have a strong commitment to solidarity was perceived to have been influenced by the wider political spectrum. It was a commonly expressed view by teachers and lay officials that the NUT did not want to be the public-sector union to challenge the New Labour government. While this may or may not be the case, the relationship between a Labour government and trade unions is always uneasy, and strategies and actions remain open to interpretation. However, as McIlroy (2000) argues, the NUT is one of the public-sector unions making strong challenges to New Labour.

\section{Conclusions}

The case study of Parkville supports findings by Fairbrother $(1994,1996)$ and Thornley (1998) on the relationship between increased managerialism and increased industrial relations activity in the workplace. Devolved management initiatives drew the headteacher and staff into conflict and negotiation that would previously have occurred outside the school. This sharpened the awareness of power relations and led to some contestation over scarce resources, thus building on the solidaristic collectivism already evident in the school and in teaching generally. Sites of resistance were practices (e.g. appraisal, redundancy and competency) associated with new managerialism. 
By exploring the interrelationship between local leadership and political activism, this case study demonstrates how SWP activists bring their politics into the workplace. There is an expectation that SWP members will take an active part in workplace industrial relations and that such activists will take on leadership roles, formally or informally, in their workplace unions. This study provided such an example. However, it should not be assumed that the relationship between political and trade union activism is inevitable: the second known SWP member in the case study school opted for a less visibly activist role. Nevertheless, in the NUT the relatively strong presence across the union of such activists will continually fuel their commitment and involvement. This provides further support to the findings of Darlington $(1994,1998,2001)$ and Fosh (1993) regarding the importance of the role of local leadership in trade unions, and to the view put forward by Darlington (1998, 2001) and Gall (1998) that union activism can be attributed to the influence of socialist politics. This is not to suggest that union members are passive actors who simply take on board what union leaders dictate. Union leaders reflect members' views but also interpret events and help shape views; using terms from the Donovan Commission (Donovan 1968), but refuting its analysis, they are both 'lubricant and irritant'.

While this case has focused on the workplace activities of left-wing political activists, it is important to recognize that the issues with which they engaged were mainstream industrial relations activities associated with the conventional struggle for control that characterizes all such activity. From this perspective, it becomes clear that it was not just 
the 'SWP factor' that led to the labelling of the teachers in this school as 'militant': it was their preparedness to resist.

The discussion on representation and oligarchy illustrated the uneven relationship between trade unions and their members (see McIlroy 2000) and is evident in this case. Indeed, the case suggests that factional influence is mediated by local and national policy-making, indicating no necessary relationship between faction and union democracy, but rather that the context will be critical. Such arguments are inevitably problematic, in that it is not possible to assess the union response in conditions where there were no political activists. Nevertheless, in line with Cornfield (1993) and Seifert's (1987) insights, pressure from union members and the factional involvement was not sufficient to persuade the union to have an earlier strike ballot. The internal and external conditions in which the school operated mitigated against the more participatory (democratic) processes. Legislation, the current political agenda, new managerialism and the public maligning of the teachers and teaching in the school - all mediated against a receptive union response. While this paper has indicated the significance of new managerialism and political activism in building workplace activity, the mutual support between levels of union members and leaders is more contested. However, this interpretation is only a partial account. After the closure of the school, the authority agreed to settle the unfair dismissal case of the union representative; paradoxically, despite his perceived militant role in Parkville, he is now teaching in the new school and, it would not be unreasonable to conjecture, recruiting union members. Ultimately, mutual support of members by union is also an important part of the account. 
This study suggests that the dynamic nature of workplace industrial relations indicates the constant and complex interrelationship between the renewal process, with both resilience and retreat. Debates on trade union renewal and resilience have to be seen in the context of the specific conditions of the workplace. It could be argued that the study indicates neither renewal nor resilience in Parkville, but retreat. Retreat is not related to 'union death' (Colling 1995) but is a predictable response in a union-oriented situation where management holds all the resources and, as in this case, is able to close down a workplace. As at Parkville, there will be circumstances where workers may experience heightened activism but meet the conditions that negate the transformation of this activity to renewal (through the processes identified by Fairbrother, 2000a), and that could arguably lead to retreat. Indeed, in Parkville the conditions were not conducive to renewal in a numerical sense, i.e. an increase in union members. However, as the case indicates, renewal should be seen as a dynamic and not purely a workplace-specific concept. In terms of awareness of the role and importance of workplace industrial relations, it could be argued that the conditions the teachers faced in Parkville enhanced a sense of collectivism, which will become part of the frame of reference through which they will interpret future workplace relations. Workers and union members bring their experiences and politics with them into the workplace; the experiences of teachers at Parkville will undoubtedly influence their future interpretation of management actions and union response and their preparedness to take action. 
There is no claim to be able to generalize from the experience of Parkville, a school facing the extreme effects of government reform and at the same time one with its own workplace industrial relations culture and specific set of conditions. The value lies in the analysis of the processes and meanings of the key actors at the micro level and of their reaction to macro and micro events. Case studies in other schools would not necessarily replicate the events at Parkville; however, in the context of perpetual educational change, it is likely that many of the issues and uneven patterns that emerged at Parkville may be of relevance elsewhere.

\section{Acknowledgements}

An earlier version of the paper was presented at the 14th AIRAANZ Conference in Newcastle, New South Wales, in January 2000. We acknowledge the valuable comments from Linda Dickens and the anonymous referees.

\section{Notes}

1. 'Parkville' is a pseudonym.

2. These are based on national examination results; British children are (unusually from an international perspective) subject to national examinations, General Certificate of Education (GCSE), at the age of 16.

3. There are three long-standing groupings: the Socialist Teachers Alliance (STA), the Campaign for a Democratic Fighting Union (CDFU) and the SWP.

4. The themes for investigation were initially informed by a quantitative survey of 3600 unionized schoolteachers (with a 52 per cent response rate) which identified 
the extent of management change in schools (Healy 1997, 1999). The survey provided extensive data on management practices, careers, unionization, etc.

5. At the start of the research there were 36 teachers in the school, some of whom left during the 'closing' phase and were replaced by long-term supply staff. When the school finally closed there were approximately 24 teachers, 18 of whom were members of the original staff; with the exception of one who refused, all of the latter were interviewed.

6. This initiative was introduced by New Labour in their White Paper Excellence in Schools (July 1997). Schools under this programme may either be taken over by another 'successful' school in the area or be closed and reopened with a new name and usually a new headteacher. Change has to be 'more than superficial' in order for the school to improve (telephone conversation with DfEE).

7. Document and media references are withheld to ensure anonymity for the school.

8. Why he had taken the role, or his passive approach to the role, is not known since he refused to be interviewed. Indeed, another teacher was the union safety representative.

9. Henceforth the term 'union representative' will refer to the SWP member.

10. These are formal procedures to monitor the performance of teachers who are considered to be 'unable to meet the requirements of the post' (Ironside and Seifert 1995: 203); failure to reach the desired standards may ultimately lead to dismissal. 
11. During fieldwork, the regional union office sent a car to take the teacher to an interview she did not wish to attend. The teacher was not expecting the car and only reluctantly attended the interview.

\section{References}

Ball, S. J. (1987). The Micro-politics of the School: Towards a Theory of School Organization. London and New York: Methuen.

- (1994). Education Reform: A Critical Post-structural Approach. Buckingham: Open University Press.

Callinicos, A. (1995). Socialists in the Trade Unions. London: Bookmarks.

Carter, B. and Poynter, G. (1999). 'Unions in a changing climate: MSF and Unison experiences in the new public sector'. Industrial Relations Journal, 30: 499-513.

Colling, T. (1995). 'Renewal or rigor mortis: union responses to contracting in local government'. Industrial Relations Journal, 26: 134-45.

Cornfield, D. (1993). 'Integrating US labour leadership'. Research in Sociology of Organizations, 12: 51-74.

Darlington, R. (1994). The Dynamics of Workplace Unionism. London: Mansell.

- (1998). 'Workplace union resilience in the Merseyside Fire Brigade'. Industrial

Relations Journal, 29: 58-73.

- (2001). 'Union militancy and left-wing leadership on London Underground'. Industrial Relations Journal, 32: 2-21. 
Donovan, L. (1968). Royal Commission on Trade Unions and Employers' Associations 1965-68. London: HMSO.

Fairbrother, P. (1990). 'The contours of local trade unionism in a period of restructuring'. In P. Fosh and E. Heery (eds.), Trade Unions and their Members: Studies in Union Democracy and Organization. London: Macmillan.

- (1994). Politics and the State as Employer. London: Mansell.

- (1996). 'Workplace trade unionism in the state sector'. In P. Ackers, C. Smith and P. Smith (eds.), The New Workplace and Trade Unions. London: Routledge, pp. $110-48$.

- (2000a). 'British trade unions facing the future'. Capital and Class, 71 (Summer): 47-78. - (2000b). Trade Unions at the Crossroads. London: Mansell.

Fitzgerald, I. and Stirling, J. (1999). 'A slow burning flame? Organizational change and industrial relations in the fire service'. Industrial Relations Journal, 30: 46-60.

Fosh, P. (1993). 'Membership participation in workplace unionism: the possibility of union renewal'. British Journal of Industrial Relations, 31: 577-92.

Gall, G. (1998). 'The prospects for workplace trade unionism: evaluating Fairbrother's union renewal thesis'. Capital \& Class, 66 (Autumn): 149-57.

Greene, A.-M., Black, J. and Ackers, P. (2000). 'The union makes us strong? A study of the dynamics of workplace union leadership at two UK manufacturing plants'. British Journal of Industrial Relations, 38: 75-93.

Healy, G. (1997). 'The industrial relations of appraisal: the case of teachers'. Industrial Relations Journal, 28: 206-20. 
Healy, G. (1999). 'The trade union role in career development: a membership perspective'. Industrial Relations Journal, 30: 212-28.

- and Kirton, G. (2000). 'Women, power and trade union government in the UK'. British Journal of Industrial Relations, 38: 343-60.

Hoggett, P. (1996). 'New modes of control in the public services'. Public Administration, 74: 9-32.

Ironside, M. and Seifert, R. (1995). Industrial Relations in Schools. London: Routledge. Kelly, J. (1998). Rethinking Industrial Relations: Mobilization, Collectivism and Long Waves. London: Routledge.

- and Heery, E. (1994). Working for the Union. Cambridge: Cambridge University Press.

Lipsett, S. M., Trow, M. A. and Coleman, J. S. (1956). Union Democracy. Glencoe, Ill.: Free Press.

Martin, R. (1968). 'Union democracy: an explanatory framework'. Sociology, 2: 205-20.

Mcllroy, J. (1995). Trade Unions in Britain Today. Manchester: Manchester University Press.

- (2000). 'New labour, new unions, new left'. Capital \& Class, 71: 11-45.

Michels, R. (1915). Political Parties: A Sociological Study of the Oligarchical Tendencies of Modern Democracies. New York: Free Press.

Seifert, R. (1984). 'Some aspects of factional opposition: rank and file and the National Union of Teachers 1967-1982'. British Journal of Industrial Relations, 22: 372-90.

- (1987). Teacher Militancy: A History of Teacher Strikes 1896-1987. Lewes: Falmer Press. 
Shepherd, H. A. (1949). 'Democratic control in a labour union'. American Journal of Sociology, 54: 311-16.

Sinclair, J., Ironside, M. and Seifert, R. (1996). 'Classroom struggle? Market oriented education reforms and their impact on the teacher labour process'. Work Employment \& Society, 10: 641-61.

Thornley, C. (1998). 'Contesting local pay: the decentralization of collective bargaining in the NHS'. British Journal of Industrial Relations, 36: 413-34.

Webb, B. (1915). 'Special Supplement on English teachers and their professional organization'. The New Statesman, 25 September 1915. 